DOI: 10.18413/2408-9338-2021-7-2-0-11

Guest Editor's Closing Post

\title{
Critical Social Theorizing in the Age of Digitalized Alienation: Overview of the Global Roundtable «Critical Theory Today: Heritage and Usage»
}

\author{
St. Petersburg State University \\ 7-9, Universitetskaya Emb., St. Petersburg, 199034, Russia \\ dvi1967@gmail.com
}

\begin{abstract}
The article is an overview of the virtual meeting of researchers who are developing critical theory of society in different forms and in different countries. The global roundtable was organized around 9 main presentations made by leading critical theorists. Preserving basic ideas from the Frankfurt school and other lines of Marxism and neo-Marxism, critical theorists are working to open new sources for development of rational and at the same time humanist and contextualized critique of new forms of alienation (including digital one) and new forms of oppression (including neocolonialist one). Participants of the global roundtable have shared idea of permanent reflection aimed at continuation of the critical theorizing and at the emancipation of human beings.

Key words: critical theory, global roundtable, digitalized alienation, emancipation Acknowledgements. This work is based on research supported by the Russian Science Foundation (the grant number 21-18-00125).

Information for citation: Ivanov, D. V. (2021), "Critical Social Theorizing in the Age of Digitalized Alienation: Overview of the Global Roundtable "Critical Theory Today: Heritage and Usage", Research Result. Sociology and management, 7 (2), 144-155, DOI: 10.18413/2408-9338-2021-7-2-0-11.
\end{abstract}

Заключительная статья главного редактора

Критическая социальная теория в эпоху цифрового отчуждения: обзор глобального круглого стола «Критическая теория сегодня: наследие и применение»

Санкт-Петербургский государственный университет Россия, Санкт-Петербург, Университетская набережная, д. 7-9, 199034 dvi1967@gmail.com

Аннотация: Статья представляет обзор виртуальной встречи исследователей, развивающих критическую теорию общества в различных формах в разных странах. Глобальный круглый стол был организован вокруг 9 основных докладов ведущих теоретиков. Сохраняя базовые идеи Франкфуртской школы и других марксистских и неомарксистских течений, теоретики работают над открытием новых источников для развития рациональной и в то же время гуманистической и контекстуализированной 
критики новых форм отчуждения (включая цифровое) и новых форм подавления (включая неоколониализм). Участники глобального круглого стола разделяют идею перманентной рефлексии, нацеленной на продолжение критической рефлексии и на эмансипацию людей от новых форм порабощения.

Ключевые слова: критическая теория, глобальный круглый стол, цифровое отчуждение, эмансипация

Благодарность: Статья подготовлена в рамках исследования, поддержанного грантом РНФ (проект № 21-18-00125).

Информация для цитирования: Иванов Д. В. Критическая социальная теория в эпоху цифрового отчуждения: обзор глобального круглого стола «Критическая теория сегодня: наследие и применение» // Научный результат. Социология и управление. 2021. Т. 7, № 2. C. 144-155. DOI: 10.18413/2408-9338-2021-7-2-0-11.

Introduction. Organizing a global roundtable on critical social theory. Restrictions on social activities in the period of COVID-19 pandemics have impacted (among other social structures and interactions) academic exchanges and scientific communications. Traditional conferences were cancelled or postponed and new distant and digital forms of communication become critically important for international academic community. Overcoming new alienation arising among scholars due to institutionalization of pandemic fears, sociologists at St. Petersburg state university (Russia) organized on the Zoom platform the global roundtable 'Critical Theory Today: Heritage and Usage'. Reflections on rising alienation and new forms of unfreedom are becoming more and more relevant in today's world. That motivates many social theorists return to ideas developed in the framework of critical theory based on the principles of reflexivity and negativity in relation to current social conditions (Horkheimer, 1982). Critical theory of society after intense development during the $20^{\text {th }}$ century in the neo-Marxist way has become a part of sociological canon (Calhoun and Karaganis, 2001). But new tendencies of social change across the Western and especially non-Western countries require broader conceptual platform to elaborate critical theoretical models relevant to current social and cultural conditions.

Idea of meeting devoted to contemporary critical social theory was proposed by Iranian social theorist Seyed Javad Miri. Conceptual and organizational design of the new event called the 'global roundtable' was made by Russian sociologist Dmitry Ivanov. On April 26, the group of scholars from different countries and continents discussed historical roots of critical theory, current state of arts in critical theorizing, and its prospects. The 9 researchers presented their views of critical theory in two rounds of discussion. Each round was about one and half hour and provided key speakers and other participants from different time zones around the globe (from Singapore, Russia, Iran, Turkey, Italy, Great Britain, the USA) with possibility to contribute into debate.

Questions proposed to discussion were as follows:

- What are traces and places of critical theory in today's social science?

- How can we use critical theorizing patterns inherited from Marxism and neoMarxism?

- Should we use the 'critical' as just a label for new leftist conceptualizations or 
otherwise return to classical dialectics of critical and traditional?

- How critical or traditional is neoMarxist theory after poststructuralist / postmodernist turn to theorizing the discursive formations?

- Does emergence of postcolonial theorizing open the next stage of critical theory development?

- Being anti-metaphysical in the $19^{\text {th }}$ century and anti-positivist in the $20^{\text {th }}$ century, can / should the critical theory now be anticonstructionist?

- What emancipation utopias can be derived from current capitalism contradictions and anti-establishment movements?

Research Results and Discussion. The first round: debating notion, sources, and relevance of critical theory.

Seyed Javad Miri opened and moderated discussion during the whole event. Seyed Javad Miri is Swedish-Iranian social theorist currently working at Institute of Humanities and Cultural Studies in Tehran, Iran. His recent works include Revisiting the Critical Theory of Syed Hussain Alatas (Brill, 2021), Frantz Fanon and Emancipatory Social Theory: A View from the Wretched (2019), Ali Shariati and the Future of Social Theory: Religion, Revolution and the Role of the Intellectual (2017), Malcolm X: From Political Eschatology to Religious Revolutionary (2016).

Opening the global roundtable, Seyed Javad Miri asked contributors give us historical and at the same time practical picture of critical social theory including ways of implementation of its emancipative and normative concepts.

Michael Naughton started discussion with speech about of the critical social theorizing engagement in human rights defense in the context of legal system which is invested by power relations. Michael Naughton is a social theorist and a reader in sociology and law across the Law School and School of Sociology, Politics and International Studies (SPAIS) at the
University of Bristol, UK. He is author or sole editor of four books, including The Innocent and the Criminal Justice System (Palgrave Macmillan, 2013) and Rethinking Miscarriages of Justice: Beyond the Tip of the 'Iceberg' (Palgrave Macmillan, 2007).

Michael Naughton said his research started about 20 years ago as very abstract and quite theoretical but later turned into practical and activist. Critical theory for him personally is about truth, justice and equality. It is also about challenging power relations. Key theorists for a such kind of theorizing are M. Foucault and K. Marx. However, critical theorizing can be revealed in more traditional theories which are not critical, generally speaking, but they are critical and radical in some aspects. For instance, E. Durkheim's conception of solidarity or M. Weber's conception of rational authority.

The research and activism in the area of assistance to convicted and imprisoned people relay on the reading Foucault's understanding power as a discourse or as a knowledgepower. The researcher's goal is to give voice to subjugated discourses in games of power. Social theory is in such case a dynamic force in an activism. That is a theory the students really need. Students in today's universities consider social theory as reluctant because even after compulsory courses of social theory they don't know which social theory can be used to explain social problems they study. Michael Naughton's own experience of presenting academic articles as arguments in the court to defend rights of convicted people can be qualified as cases of critical theory practical usage. That is activism inspired by critical social theory in broad meaning of this term.

Defining critical theory as an understanding how society works to utilize it to make changes in society, researcher can use Durkheim's idea of solidarity. According to Durkheim crime punishment has to maintain solidarity in society. But unjust conviction, disproportional exercise of power to working class people and ethnic minorities provoke protests and undermine normal 
functioning of communities. That undermines solidarity. Critical social theory can help us to change legal system making it more reflexive and more sensitive to public opinion. Priority should be given to substantial justice and not to formal one. This distinction based on Weber's ideas also can be considered as a part of critical social theory. Procedure doesn't provide the truth and justice and dominant discourse in the legal system should be criticized with use of various sources of social theorizing.

Syed Farid Alatas continued discussion expressing his sympathy to Michael Naughton's approach to critical theory as having emancipatory, deliberating potential to deconstruct and to demystify social order. Seyed Farid Alatas is professor of sociology at the National University of Singapore. He has authored numerous books and articles, including Sociological Theory beyond the Canon (with Vineeta Sinha, Palgrave, 2017), Applying Ibn Khaldun: The Recovery of a Lost Tradition in Sociology (Routledge, 2014). His areas of interest are the sociology of Islam, social theory, religion and reform, and the study of Orientalism.

Seyed Farid Alatas proposed to discuss different sources of critical theorizing. Western tradition presented by Marx and by thinkers inspired by Marx, including those mentioned by Michael Naughton, is important. But there are intellectual sources outside European tradition or Euro-American tradition. Because of Eurocentric domination and because of intellectual imperialism many resources for critical theorizing are unknown. Some of such resources are not presented in curricula. For example, everyone among us knows about W. Dubois and other thinkers belonging to pan-African tradition of social critique. But they mostly are not included in the introductory courses on social sciences. In some cases, thinkers are so much marginalized that they become very obscure. One of such thinkers who studied colonial regime was Jose Rizal in Philippines at the $19^{\text {th }}$ century. Many thinkers contributed to fundamentals of social sciences in that formative period. They analyzed society critically and inspired oppositional, anticolonial and revolutionary movements. This is the problem of Eurocentrism. Decolonization of knowledge now is related to BLM movement which has influenced academia and has impacted campuses in the USA and UK. At the same time in the context of Malaysia and other Muslim countries intellectual domination and hegemony lead to exclusion of non-European thinkers and also women who contributed to history of social sciences.

Another form of hegemony in knowledge production is the state control and authoritarianism. Non-democratic regimes restrict possibilities to develop researches and theories which deconstruct mythology supporting power and inequalities. The state and religious authorities are controlling academic discourses including the banning books. One more 'ism' creating problems for social theory is sectarianism. In Malaysia, for example, sectarianism takes form of antiShiaism (hate speech supported by the state, disinformation about Shia history, oppression of Shia culture etc.). One more example is ethnonationalism arising in Myanmar in the form of Buddhist fundamentalism and oppression of Muslim and Hindu minorities. Ultranationalism impacts academic discourses. So, Eurocentrism is only one of problems we face on the way to critical emancipatory social knowledge. Our academics are involved in demystifying of the dominant constructions of reality and in intervening in the real life of people. But not at high extent. For example, criticizing antiShia discourses as based on stereotypes and false interpretations of history of Islam. Generally speaking, Malaysian academics don't use intensively tools and legacy of social theory to intervene in the social life.

Dmitry Ivanov in his presentation 'Critical Theory and Dialectics of Modernity' returned discussion to classical Western roots of critical social theorizing and to the question of its relevance under conditions pf postindustrial capitalism. Dmitry Ivanov is 
full professor of sociology at St. Petersburg State University, Russia. He is the author of several books published in Russian including Virtualization of Society (2000) and GlamCapitalism (2008). His recent international publications are 'Post-globalization, Postvirtualization, and New Inequalities' in the book Changing Democracies in an Unequal World (Franco Angeli Open Access, 2020) and 'New Configurations of Inequality and Glam-Capitalism Structures' in the book Global Inequalities in World-Systems Perspective. (Routledge, 2017).

Dmitry Ivanov distinguished two lines in the development of critical theory: Kantian neo-Marxism by M. Horkheimer and Hegelian neo-Marxism by H. Marcuse. The society as permanent dialectical negation and empirically-based utopianism had enabled $\mathrm{H}$. Marcuse's critical theory to reveal the direction of modern society transformation in the $20^{\text {th }}$ century. Hegelian paradigm 'Thesis Antithesis - Synthesis' takes form of dialectical negation in Marcuse's development of notion of freedom: Reason Eros - Post-technological rationality.

Utopia of 'Reason' (rationalized society) formulated by Marcuse in the 1930s was derived from leftist revolutionary movements, but by the 1940s the rationalization thesis had become an affirmative discourse for arising organized capitalism (large corporations, labor unions, welfare state).

Utopia of 'Eros' (desublimated society) formulated in the $1950 \mathrm{~s}$ as dialectical antithesis for rationalization was extracted from marginal values and alternative lifestyles of esthetic communities and hedonistic subcultures of radical intellectuals. By the 1960s the concept of desublimation turned from critical idea into descriptive and affirmative discourse for affluent society providing managed satisfaction of socially constructed needs and desires of consumers. That motivated Marcuse to renew dialectical theorizing as the negative analysis of the reified system absorbing the alienated existence in the one-dimensional society.
Utopia of 'Post-technological rationality' (the 'Great Refusal' and new sensibility leading toward open multidimensional society). The new antisystem concept formulated in the 1960s as dialectical synthesis of 'Reason' and 'Eros' presented new social movements (antiwar, feminist, ecologist, for civil rights of minorities) as movements of difference. By the end of the 20th century the concept of post-technological rationality became affirmative discourse for the system of postindustrial capitalism. The Great Refusal of outsiders resulted in a 'multi-dimensional society' as the system of administered tolerance, diversity, inclusive citizenship, multiculturalism, and positive discrimination of minorities. Reified system has absorbed outsiders as new forms of social control are inclusive and impose diversity on people.

An unintended result of three decades of critical theorizing is a general pattern of Modernity dialectics. The system normalizing unfreedom and anti-system movements refusing normativity are interrelated in dialectical way: anti-system utopias of the marginalized outsiders and protest movements oppressed by dominant structures of the present turn into sources for the dominant structures and patterns of agency in the future. Dialectical pattern 'system - antisystem outsiders - new form of sociality' can be seen in virtualization of society during last decades of the $20^{\text {th }}$ century.

Virtualization is replacement of things and real actions by images and communications. Virtualization was the antisystem movement in the 1980-90s when digital technologies enthusiasts created virtual networks escaping control of reified institutions. But now that 'Great Escape' of cyberpunks, hackers, pirates, and copyleft activists has been absorbed by the system. Contemporary postindustrial capitalism is based on virtualization of production and consumption and on compulsory use of digital platforms. Commodification of images takes form of branding that generates enormous market value in current economy. 
Capitalization on images intensifies communications and makes network the most relevant organization structure. Social life is alienated into virtual realities of branding, image making, and digital networking. The current cycle of Modernity dialectics is negation of virtualization by anti-virtual turn to 'new materiality' and then its negation in post-virtualization as a rise of augmented social reality.

Dialectical negation now is driven by movements representing the new utopia: authenticity revolt against virtuality. Commodifying images, current capitalism of brands and trends alienates identity as fundamental component of social existence. That provokes counter-movements for authenticity and against ephemeral but powerful structures of current capitalism. On the line of confrontation between glamour of postindustrial capitalism and alternative reality of craft and sharing the newest forms of commodification and protest in urban spaces are converging on the move towards the system of alter-capitalism. Postvirtualization creates social life as an existence full of cyber-physical experience. Different social realities are mutually penetrated and take form of augmented reality integrating physical and digital, material and symbolic, modern and 'postmodern' components of human life.

The next phase of dialectic of Modernity is rooted in the contradiction between augmented social reality emerging in the global cities as super-urban enclaves and exhausted sociality in small cities and rural communities which are losing material, symbolic, and human resources 'washed away' by flows directed towards super-urban hubs of globalization and virtualization. 'Augmented Modernity' contrasted with 'Exhausted Modernity' can be a starting point for the future critical theory of society.

Using Marcuse's model of critical theorizing as permanent dialectical negation we can say Marxism is now an affirmative discourse. Neo-Marxism also is affirmative discourse. We have to identify among outsiders of contemporary society new liberation movement being political or cultural and to reveal ways of it becoming a source for the newest form of social control and normativity. That is paradox or dialectic of critical theory. The general task for the next phase of critical theorizing can be formulated like it was done on the Marcuse's grave stone in German cemetery: 'weitermachen!' (let's continue!).

Yuri Asochakov focused his speech on the question 'What are traces and places of critical theory in today's social science?'. Yuri Asochakov is associate professor at St. Petersburg State University, Russia. He studied post-Hegelian philosophy and genesis of critical theory. His recent publications are dedicated to digital inequality and to postglobalization.

Yuri Asochakov said that in the theoretical field of sociology, two types of theory are clearly distinguished. Stabilizing Theories are aimed at description of society and creating its theoretical models. Theories of this type are aimed at explaining and legitimizing the established way of life of society. Those theories are methodologically objectivism-oriented, expanding their empirical basis, systematizing present sociopolitical discourse, and searching for a project of optimal stable functional model for the current order of society's life. Another type of theory is focused on creating a project of radical fundamental changes in the existence of society, carrying solutions to problems, often hidden and invisible for stabilizing theories. The theories of the critical type are activism-oriented, aimed at describing the process of society's life, rather than its empirical structural manifestation. They base analysis on a speculative-projective way of thinking.

The presence of these two types of social theories is necessary to solve the practical problems of the existence of society which, like any systemic object, must resolve the problems of preservation and stability and at the same time be ready for changes. 
These two types of social theories form two poles of the theoretical field in which particular theories gravitate to either one or other type. The theories that most fully embody these tendencies (stabilization and critique) are distinguished in the history of sociology of the periods of the First Modernity (Classical capitalism of the $19^{\text {th }}$ century) and the Second Modernity (Modern industrial society of the $20^{\text {th }}$ century) and are presented as theoretical oppositions placed asymmetrically: stabilizing theories occupy the dominant center defining the mainstream of socio-political discourse (and looking like ideologically repressive discourse of structure). Critical theories are located on the periphery and they define the so-called 'discourse of liberation'.

What happens during our transition to a new phase of Modernity, to an Information Society or a Digital Society? The main perspectives and illusions, as in the periods of any phase of transition, are related to the technological factors of the transition.

The transition to the Third Modernity is mainly associated with the emergence of new communication technologies and primarily the internet which makes it possible to understand the essence of this transition as a virtualization of society (i.e., the emergence of a new dimension of human existence where there are new features and prospects). The internet and the Digital Society were understood as the territory of freedom where the main limitations of the Modernity of the Analogue period (inequality, hierarchical dominance, repressive regime) were overcome or weakened. The network organization of structures with the absence of the principle of hierarchy, center, repression, and the institutionalization of the multiplicity of life-worlds were assumed by the proponents of these theories (cyberutopianism) to be the main perspective for the development of a new society.

What today can constitute a critical pole in the theoretical field of social science? These are theories that indicate that the new digital world is based on the same principles as the analogue world, but those limitations and exceptions are becoming more hidden. Relativistic approach motivates us to say that the solution to one problem generates new ones. Appropriate theoretical efforts are needed to understand the nature of the new digital alienation and the new form of the problem of freedom, and first of all in the mode of critical thinking. The simplest form of it is now cyber-skepticism. There is reason to believe that a previous structure based on the opposition of stabilizing theory and critical theory will remain in today's theoretical field. A meaningful critical interpretation of the new society should be more theoretically advanced than straight criticism of theories caused by cyberoptimism and cyber-utopianism.

The second round: contextualizing critical theory in the humanity space and time.

Stephen Turner opened the second round of the global roundtable with his presentation 'Critical Theory or Left Schmittianism?'. Stephen Turner is distinguished university professor at the Department of Philosophy at University of South Florida. He has written extensively on the issues in social and political theory, especially related to Max Weber and his critics, on liberalism, populism, and the administrative state.

Stephen Turner revealed parallels in critical theorizing of Frankfurt School and K. Schmitt's political philosophy. Critical theory was a response to the failure of the proletariat to fulfill its historic revolutionary destiny of overturning capitalism, liberalism, the bourgeoisie, and so on. The socialist idea lost steam after the establishment of eighthour day. Socialism as an ideal hung on, but changed form, suffered from internal conflicts, became subordinated to Soviet foreign policy and discipline, etc. Left thinkers adopted Schmittian logic presupposing that every religious, moral, economic, ethical, or other antithesis transforms into a political one if it is sufficiently strong to group human beings 
effectively according to distinction 'friend or enemy'. All concepts in critical theory become political and confrontation-oriented. For example, Marcuse defined the term of tolerance in that way: tolerance is a term which negates the possibility of revolutionary truth and thus is a form of intolerance of anything but the acceptable liberal standpoints, which it labels as intolerant, and "tolerance" is therefore a form of oppression. Kirchheimer did the same with term of justice: there is no such thing as non-political justice.

Critical legal studies represent one of dominant discourses in the critical theorizing in the USA. Critical legal studies are projected as inspired by critical theory but the basic ideas are Schmittian. Key idea is that such thing as legal neutrality doesn't exist. Law is policy, judges and lawyers are policy makers. The idea of applying the law and the rule of law is for second rate lawyers. The elite understands and should understand its role as political. The elite of law are the sources of social justice. The critique of liberalism is exemplified by feminist jurisprudence which is very influential now. This approach in works by C. MacKinnon presupposes that liberal morality cannot deal with illusions that constitute reality because its theory of reality, lacking a critique of the distribution of social power, cannot get behind the empirical world, truth by correspondence. On the surface, both pornography and the law of obscenity are about sex. But in fact, it is the status of women that is at stake. Gender neutral and objective formulations avoid asking whose expression, from which point of view? Whose law and order? The fact is that what we see, what we are allowed to experience, even in our own suffering, is overwhelmingly constructed from a male point of view.

Critical race theory continues that logic. Purported basis is critical legal studies (strong focus on law and then on oppression. Now theory expands to non-legal forms of oppression, meaning anything that produces difference that favors the dominant group.
Black is substituted for women, white for male. The list of non-neutral topics expands to include such things as mathematics. Subdivisions are added to accommodate the fact that the multiplication of perspectives means that people are in multiple categories. This is intersectionality: thus, Black Lesbian Women are in a specific category of oppression. Adding Marxian false consciousness to Schmittian anti-neutrality in each of these cases produces the following: The actual victims of oppression are additionally oppressed by their false beliefs in liberal neutrality. The overcoming of these false beliefs depends on education. Education depends not on (inevitably distorted) actual experience, but on experts. Consciousness raising, coercive educational methods, and the like are needed to produce the correct expertderived form of consciousness.

The "critical" part in the critical theorizing, after the Marxist teleology is abandoned, comes down to anti-liberalism. This is better understood in Schmittian terms: against economic neutrality, or neoliberalism, and against political neutrality, meaning political institutions whose neutrality disadvantages any identity group with its own solidaristic unity. But because these solidarities, concepts of justice, emancipation, etc. conflict with one another and have different bases, they need a common enemy. They also need a common myth about future universal solidarity, as an alternative to the rule-bound neutrality of the liberal order. This means a state and institutions which employ direct means, such as redistribution, not the indirect means of liberalism.

There is no a coherent ideology in such critical studies but the 'friend-enemy' grouping in the oppression paradigm is obvious. Such categories as Jews, "capitalism," the richest $1 \%$, white males, Republicans, Evangelicals, the police are confronted with Feminists, Islamists, POCs, the formerly colonized, anti-fascists, the poor, Palestinians, migrants, Iran, China, Africa and other oppressed countries. The confrontation logic leads to some paradoxes. If perspectives 
determine what oppression is, and perspectives are irreducibly in conflict, and the goal is "emancipation," i.e., the elimination of oppression without the production of new forms of oppression, the obvious non-violent solution is a neutral legal regime, such as a democracy. But neutrality is itself oppressive if it conflicts with any perspective. The questioned is solidarity: is it in a new form - inclusion - the solution? Is this coherent, or just a negation? In political aspect, can these emancipatory movements add up to anything other than a new totalizing political expression that is itself repressive?

The liberal answer is "no." The metamorphosis of moral ideals into law transforms "justice" into a machine of coercion. There is no magic solution to the problem of different conceptions of justice, and democratic majoritarianism, with protections for minorities, is still the best solution. The Left answer is "yes." The old teleology of the march to socialism was right, and universal solidarity and the replacement of politics with the administration of things is still possible. We are now there, in this point of debates.

Rudolf Siebert presented conceptual fundamentals of his theory of religion developed out the critical theory of the Frankfurt school. Rudolf Siebert is professor at Olivet College in Michigan, USA. His main works are The Critical Theory of Religion: Frankfurt School and From Critical Theory to Critical Political Theology: Personal Autonomy and Universal Solidarity.

Rudolf Siebert started his studies shortly after World War II. About 25000 Germans imprisoned by the Allies were selected to be learned in anti-nazi way to restore liberal state and society. Siebert's critical theory of religion was an attempt to apply principles he learned in the Frankfurt school from M. Horkheimer and T. Adorno. $\mathrm{He}$ participated in foundation of Christian Democratic Union (CDU) as a party where workers and Christian bourgeoisie can be together. The development of critical theory of religion was presented in about 30 books and 500 articles. For the developing critical theory of religion dialectical methods were used. The negative dialectic was received from Horkheimer, Adorno, and Marcuse. But it referred to the great tradition of Kant and Hegel. Idealistic notion dialectic was combined with materialistic reality dialectic taken from Marx. In contrast with positivism, critical thinking was concerned with contradictions or antagonisms in society and knowledge. Classical ideas of Horkheimer and Adorno were integrated with J. Habermas' ideas of language competence and A. Honneth's ideas of struggle for recognition.

In the $21^{\text {st }}$ century, neo-Marxism has lost a critical power. Postcolonial studies open the next stage of the critical theory. But postcolonial theory is really critical when it includes not only identity politics but also class issues and surplus value redistribution problems. According to critical theory of religion, the emancipation utopia in the postsecular society can be derived from surplus value issue. It presupposes collective appropriation of collective labor results.

Dustin J. Byrd presented his view of critical theory in front of rising ethnonationalism and pathological critique. Dustin Byrd is associate professor at Olivet College in Michigan, USA. He is a specialist in contemporary Islamic thought and the Frankfurt School's Critical Theory of Religion. He has published extensively on critical social theory.

Dustin Byrd insists critical theory is in a precarious state at the moment. There are two destructive forces in American civil society and in the Western societies in general. The first such force is ethnonationalism attacking liberal multiculturalism and globalization. The second one is a pathological critique negating the Enlightenment with its fundamental values of liberty, equality, and fraternity. With two those forces civil society is becoming self-destructive. In reality, critical theory stands between ethnonationalism and pathological critique. 
Modern democratic citizenship undermines traditional communities and identities (Gemeinschaft). The nation now faces overdiversification. Frustrated Europeans and Euro-Americans tend to support ethnonationalism joining the far-right groups and campaigns aimed at dediversification of ethnosphere. On the other hand, pathological critique is represented by broad spectrum of the political left. We need to distinguish rational determinate negation in critical theory and irrational abstract negation characterizing many leftists today. The Enlightenment is totally negated because of history of colonialism, racism, labor exploitation, and gender domination. Pathology of this critique is rooted in abstraction and totality of negation. For example, many classics are excluded from university curricula because the authors were white men who 'propagated white supremacy'. The entire field of study like Rome history or Babylon history should be cancelled due 'whiteness' of all classics. That is called a spiritual catastrophy. The same story is with Kant, Hegel, Marx, Freud and other philosophers. From the point of view of pathological critique, even Hegel's dialectical logic is a form of racism and domination. The scientific method in general is condemned as 'white invention'.

Critical theory, especially the first and second generations of the Frankfurt school, stands in between. Critical theory shares with the new right critique of global capitalism, concern with cultural industry and market imperialism. But critical theory cannot accept biologized nationalism and demonization of migrants and refugees. Critical theory shares with other forms of leftism critique of labor exploitation, class, race, and gender domination. But it doesn't accept negation of classical philosophical and cultural foundations of liberation thinking. The negative dialectic of the Frankfurt school is not totally negative and the positive should be rediscovered in the negative dialectic. Critical theory should be preserved despite all unacceptable now elements of traditional thinking to struggle against both ethnonationalism and irrational pathological critique.

Detlev Quintern spoke from historical perspective about Marx and Marxism in an universalistic context. Detlev Quintern is assistant professor at the department of Cultural and Social Studies at TurkishGerman University, Istanbul, Turkey. His latest publication was an anthology (ed. with Kerstin Knopf) discussing Karl Marx and Marxism from several perspectives, including post-, decolonial and anti-imperial approaches.

Detlev Quintern started with statement which sounded very provocative: Marxism to some extent turned into national socialism because it imposed universalistic view on all regions of the World and all periods of history. The theory of society's evolution ignored specificity of values, social life and cultures outside Western capitalism. Traditional Marxism was optimistic. Socialism as a stage of society's development was viewed a necessity beyond particularities of ethnicities and identities. The revolutionary working class is precondition for the better free society. Critical Marxist theory deconstructs and negates this teleology. Now we have to discuss possibility of post-Marxist universalistic critical theory which would include anti-imperialist and anti-colonial texts and voices from Asia, Africa, and Americas. They should be included alongside with nonMarxist theories of community, solidarity, and freedom (for example, anarchist theory by P. Kropotkin). All views of the future better and harmonious life should be included in the new universalistic critical theory.

The cornerstones of Marxist theory have to be discussed beyond ideological bias. Marx extracted from the history the 'pure capitalism' to analyze current society and to develop theory of future society - socialism. But that 'pure capitalism' is beyond reality. The class theory based on an idea of property possession / dispossession doesn't allow us to understand specific social structure and 
foundations of anti-imperialist and anticolonial resistance in the non-Western world. Marx and Engels underestimated or even ignored the role of political violence which was so important in the genesis and expansion of real capitalism. Critical theory needs ontological meta-scientific understanding of life beyond traditional 'laboratory' of national economy with its mathematization of sociality. The values of justice and life should be fundamentals and then appropriate scientific and technical tools can be enrolled.

Seyed Javad Miri (Institute of Humanities and Cultural Studies in Tehran) intervened in the discussion with the idea of the alternative sources for critical social theory. He quoted Horkheimer's definition of critical theory from 'Dialectic of Enlightenment'. Horkheimer argued that theory is critical to the extent it seeks human emancipation from slavery. In other words, critical theory aims to transform all circumstances economic, political, religious, cultural, local or global, which enslave human beings. We have to contextualize or localize critical theorizing. Authoritarian political forces and obscurantic religious forces from one side and new colonialist policies in the form of so called 'smart sanctions' from another side work against human emancipation and enslave human beings in non-Western societies. We need the really new perspective which would be critical in non-Eurocentric way. In the recent decade, several works were published to rediscover thinkers outside Euro-Atlantic canon: Malcolm X, Ali Shariati, S. H. Alatas and others. That is done to expand our understanding of social critique and to broaden classical foundations of social theory. In this sense, we can integrate the Eastern West, Southern North etc.to understand reality shaped by tension between neocolonial and post-colonial tendencies and to act against new forms of enslavement.
Conclusion. Permanence of critical reflection. About 20 participants joined during the day of April 26, 2021 the global roundtable and participated in two rounds of discussion on heritage and usage of critical social theory. Preserving basic ideas from the Frankfurt school and other lines of Marxism and neo-Marxism, critical theorists are working to open new sources for development of rational and at the same time humanist and contextualized critique of new forms of alienation (including digital one) and new forms of oppression (including neo-colonialist one). Participants of the global roundtable have shared idea of permanent reflection aimed at continuation of the critical theorizing and at the emancipation of human beings. Seyed Javad Miri has proclaimed in his concluding remark future rounds of this global roundtable to emancipate at least theorists themselves from the newest slavery.

Considering circle of contributors and originality of their discourses, we can conclude that the attempt to draw the picture of the critical theory relevant to conditions of the $21^{\text {st }}$ century should be assessed as very successful. The intellectual network that is a result of the first global roundtable has become the fruitful source for the next global roundtable. Its title is 'Critical Social Theory: Relocating Critical / Post-Colonial Social Theory: Religion, Solidarity, Emancipation'. It was organized on May 17, 2021.

\section{References}

Calhoun, C., Karaganis, J. (2001) Critical Theory, in Handbook of Social Theory, ed. by G. Ritzer and B. Smart. London: SAGE Publications, Chapter 15, 179-200.

Horkheimer, M. (1982) Critical Theory. Selected Essays. New York: Continuum Publishing.

Статья поступила в редакцию 23 апреля 2021 2. Поступила после доработки 12 мая 2021 2. Принята к печати 30 мая 2021 г. 
Received 23 April2021. Revised 12 May 2021. Accepted 30 May 2021.

Конфликты интересов: у автора нет конфликта интересов для декларации.

Conflicts of Interest: the author has no conflict of interest to declare.
Иванов Дмитрий Владиславович, доктор социологических наук, профессор, заведующий кафедрой теории и истории социологии Санкт-Петербургского государственного университета, СанктПетербург, Россия.

Dmitriy V. Ivanov, Doctor of Philosophy, Professor, Head of the Department of Theory and History of Sociology, St. Petersburg State University, St. Petersburg, Russia. 